\title{
Soft kompütinq metodları əsasında proqram təminatının etibarlılığının təmin edilməsi
}

\author{
Tofiq Kazımov ${ }^{1}$, Tamilla Bayramova ${ }^{2}$ \\ AMEA İnformasiya Texnologiyaları İnstitutu, Bakı, Azərbaycan \\ ${ }^{1}$ tofigemail.ru, ${ }^{2}$ tamillaeiit.ab.az
}

\begin{abstract}
Xülasə-Məqalədə proqram təminatının qiymətləndirlməsi üçün soft kompütinq metodlarının tətbiqi haqqında məlumat verilmiş və bu metodlarının klassifikasiyası göstərilmişdir. Proqram təminatında olan səhvlərin müəyyən edilməsi və qərarın qəbul edilməsi üçün qeyri-səlis məntiq əsasında konseptual model verilmişdir.
\end{abstract}

Açar sözlor- soft kompütinq, qeyri-solis montiq, xaos nozəriyyasi, neyrokompüting, genetik alqoritm

\section{GİRIŞ}

Hal-hazırda xüsusi təyinatlı sistemlərin informasiya və telekommunikasiya resursları daha çox qərəzli hücumlara məruz qalır. $\mathrm{Bu}$ da ölkənin müdafiə qabiliyyəti və vətəndaşların təhlükəsizliyi üçün ciddi təhdidlər yaradır. Ona görə də proqram sistemlərinin təhlükəsizliyinin təmin edilməsi bu günün ən aktual və mürəkkəb problemlərindən biridir.

Mürəkkəb informasiya sistemlərinin yaradılma və tətbiq edilmə təcrübəsi göstərdi ki, onların istismarı zamanı baş verən problemlər əksər hallarda proqram təminatında (PT) olan səhvlərlə əlaqədardır. PT-nin kodlaşma və sınaq mərhələsində proqram kodunda olan bütün səhvlər, zəif nöqtələr aşkar edilib düzəldilməlidir. Oks halda xakerlər proqramın icra kodunda olan səhvləri taparaq öz hücumlarını reallaşdırmaq üçün istifadə edə bilərlər. Müdafiə mexanizmlərinin pozulması zamanı yarana biləcək risklərin dəyəri çox yüksək ola bilər. Məhz bu səbəbdən də PT-nin etibarlılığı onun keyfiyyət xarakteristikalarından ən vacib olanı kimi qiymətləndirilir. PT-nin etibarlılı̆̆ proqram məhsulunun verilən şəraitdə və verilən vaxt müddətində müəyyən funksiyaları kifayət qədər böyük dəqiqliklə yerinə yetirə bilmək qabiliyyətidir [1].

\section{PT-nin ETIBARLILIĞININ QIYMӘTLӘNDİRILLOSİ}

Mürəkkəb proqram sistemlərində baş verən proseslərin dinamikası, mürəkkəbliyi və qərəzli təhdidlərin yeni tiplərinin meydana gəlməsi PT-nin etibarlılığının təmin edilməsi məsələlərini daha da mürəkkəbləşdirir. PT-nin etibarlılığını birbaşa qiymətləndirmək mümkün deyil və kritik proqramlarda etibarlılığa qoyulan tələblər çox yüksək olduğundan bu sahədə görülən işlərin həcmi bir neçə dəfə artır.

PT-nin etibarlılığını təmin etmək üçün səhvlər haqqında xəbərdarlıq edən və onların qarşısını alan, eyni zamanda bu səhvlərin yaranması zamanı proqramın fəaliyyətini davam etdirməyə imkan verən effektiv metod və vasitələrin işlənilməsi və tətbiq edilməsi vacibdir.

PT-nin etibarlılığının qiymətləndirilməsi üçün müxtəlif riyazi modellər mövcuddur [2]. PT-nin etibarlılıq modelləri işlənilmə və sınaq mərhələlərində proqram təminatında olan səhvlərin sayını dəqiq proqnozlaşdırmağa, proqram məhsulunun buraxılış tarixini müəyyən etməyə, resursları düzgün bölməyə və proqram təminatının müşayiət edilməsinə lazım olan xərcləri düzgün qiymətləndirməyə imkan verir.

PT-nin etibarlılı̆̆ının qiymətləndirilməsinin klassik etibarlılıq modellərində proqram kodunun struktur xüsusiyyətləri (proqram modullarının sayı, operatorların sayı, altsistemlərin və modullararası interfeyslərin sayı, mürəkkəbliyi və s.), və sınaqlar zamanın müəyyən edilən bəzi parametrlər (imtinaların zamandan asılılığı, imtinaların sayı, səhvlərin sayı, səhvlərin tapılma müddəti və s.) əsasında hesablamalar aparılır. Bununla yanaşı proqram sistemlərinin mürəkkəbliyi, işlədiyi mühit və giriş verilənləri kimi parametrlərə əsaslanan modellər də mövcuddur.

PT-nin etibarlılıq modellərinin tətbiq edilməsi proqram məhsulu haqqında müəyyən fikir formalaşdırmağa imkan verir. $\mathrm{Bu}$ modellərdən PT-də sınaqdan sonra qalan səhvlərin sayının qiymətləndirilməsi və proqnozlaşdırılması üçün müvəffəqiyyətlə istifadə edilir. Məsələn, sınaq mərhələsində tapılmış və düzəldilmiş səhvlərin sayının çox olması belə bir fikir yaradır ki, məhsulun sınağı sona çatmaq üzrədir, çünki qalan səhvlərin sayı minimum olmuşdur. Đslində bu həqiqətə uyğun olmaya bilər və 


\section{"Informasiya tohlükosizliyinin aktual problemlori" III respublika elmi-praktiki seminarı, 08 dekabr 2017-ci il}

belə hallarda PT-nin etibarlılıq modellərinin tətbiq edilməsi məsələyə aydınlıq gətirə bilər.

Lakin bu modellərin heç biri PT-nin bütün xarakteristikalarını əhatə edə bilmir və bütün hallar üçün universal olan vahid model yoxdur.

PT-nin strukturu mürəkkəb olduqda onu tam olaraq test etmək mümkün olmur. Ona görə də son illərdə etibarlılıq modellərinin işlənilməsi zamanı intellektual analizə üstünlük verilir. Bu PT-nin etibarlılıq modellərində dəyişikliklərə uyğunlaşma, özünü bərpa etmə, yaxşı keyfiyyətlərin irsi ötürülməsi və öyrənmək kimi xüsusiyyətlərin həyata keçirilməsinə imkan verir $[3,4]$.

\section{PT-nin ETIBARLILIQ MODELLORININ QIYMӘTLӘNDIRILLMSINDD SOFT KOMPYÜTINQ METODLARININ TӘTBİQI}

Müasir informasiya texnologiyalarının innovativ istiqamətlərindən biri də PT-nin etibarlılığının təmin edilməsi sahəsində yeni yanaşmaların işlənilməsi və tətbiq edilməsidir. Verilənlərin intellektual analizi və mühəndislik bilikləri metodlarından istifadə edilməsi, süni intellekt sahəsində araşdırmalarda əldə edilən nailiyyətlər sayəsində PT-nin etibarlılıq probleminin həllində yeni istiqamətlər yaranmışıdr. Son illərdə PT-nin etibarlılığının modelləşdirilməsi və proqnozlaşdırılması sahəsində real məsələlərdə meydana gələn çətinliklərin aradan qaldırılması üçün maşın təlimi (Machine Learning) və Soft kompütinq (Soft computing) metodları tətbiqi edilməyə başlanmışdır $[5,6]$.

Soft kompütinq metodu hesablama riyaziyyatının yeni metodudur. Bu termin 1994-cü ildə Lütfi Zadə tərəfindən daxil edilmişdir və problemli sahələrdə ənənəvi metodlardan daha səmərəli nəticələr verir $[7,8]$.

$[9,10]$-da ilk dəfə olaraq proqram təminatının etibarlılığının qiymətləndirilməsi üçün neyron şəbəkə arxitekturundan istifadə edilmişdir. Bu model əsasında nasazlıqların ümumi sayının proqnozunu vermişdir.

[11]-də Soft kompütinq metodlarının klassifikasiyası göstərilmişdir (şəkil1). Müəllif 1990-c1 ildən 2014-cü ilə qədər olan müddətdə bu texnologiyaların tətbiqi ilə PT-nin etibarlılığının modelləşdirilməsinə və proqnozlaşdırılmasına həsr edilmiş 30-dan çox iş təhlil edilmiş, həmçinin PT-nin etibarlılıq modellərində tətbiq edilən müxtəlif soft kompütinq metodlarının qisa xülasəsi verilmişdir.

Son illərdə etibarlılıq modellərində ən çox istifadə edilən texnologiya neyron şəbəkələr (neural network) və qeyri səlis məntiq (fuzzy logic) olmuşdur. Lakin genetik alqoritmlər (genetic algorithm), genetik proqramlaşdırma (genetic programming), süni arı sürüsü alqoritmi (artificial bee colony algorithm ), ququ quşu (cuckoo search) alqoritminin tətbiqi ilə də modellər işlənilmişdir [12-17].

\section{SOFT-KOMPYÜTINNQ METODLARININ TӘTBİQİ İLӘ PT-nin ETIBARLILIĞININ ARTIRILNMASI ÜÇÜN KONSEPTUAL MODEL}

Yuxarıda adları çəkilən intellektual vasitələrdən istifadə etməklə proqram kodunda olan səhvlərin klassifikasiya və klasterizasiyası, risklərin qiymətləndirilməsi, vəziyyətin monitorinqinin aparılması, hadisələrin inkişafının modelləşdirilməsi və proqnozlaşdırılması, qeyri-müəyyənlik hallarında vəziyyətə uyğun qərarların qəbul edilməsi kimi məslələri həll etmək olur.

$\mathrm{Bu}$ işdə hər bir səhvin nəticəsi və bunun əsasında qərarın qəbul edilməsi üçün konseptual model verilmişdir (şəkil 2). Qeyri-səlis şərtlərdə və qaydalarda istifadə edilən verilənlər giriş linqvistik dəyişənlari, qeyri-səlis qərarlarda istifadə edilən dəyişənlər isə çıxış linqvistik dəyişənləri adlanır. 


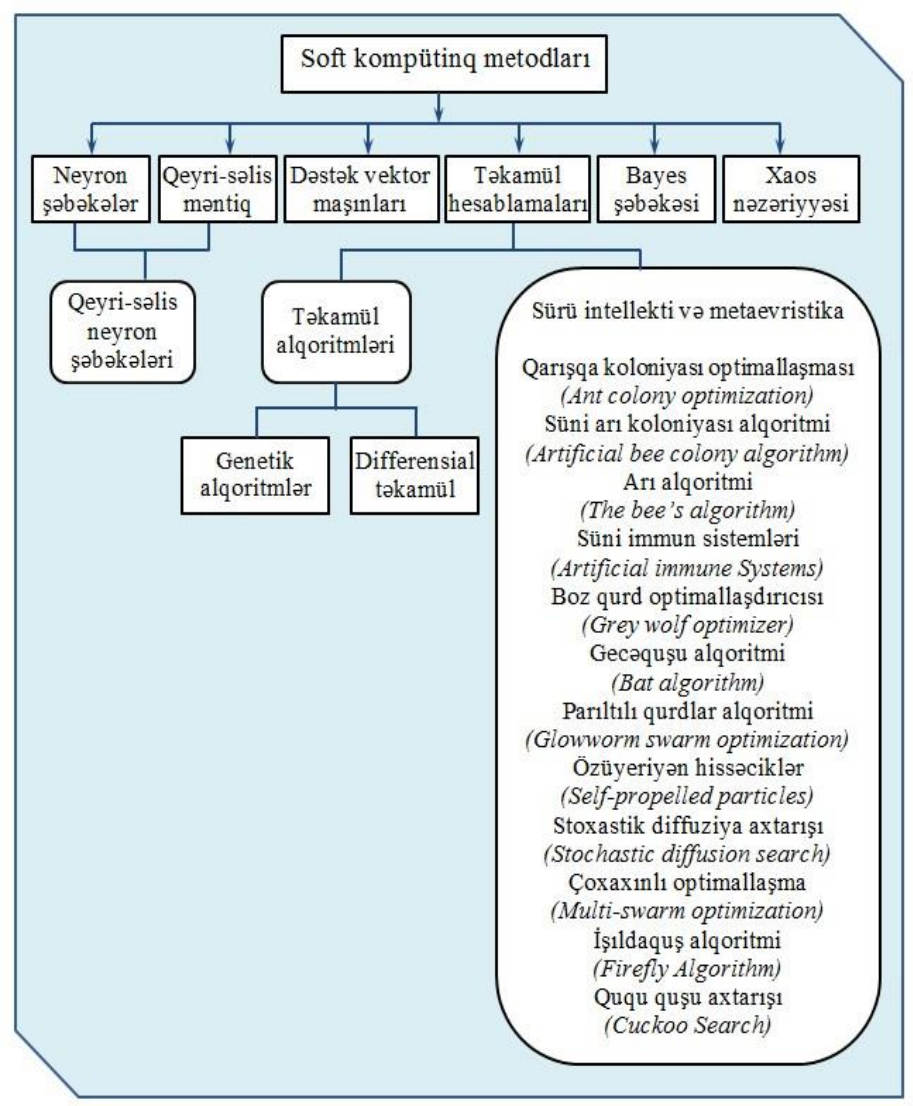

Şəkil 1. Soft kompütinq metodları

Qaydalar bazasının formalaşması zamanı qaydalar çoxluğu

$P$, giriş linqvistik dəyişənləri $F$, çıxış linqvistik dəyişənləri $D$ verilməlidir. Bu zaman həm $\alpha_{i} \in F$, həm də $\beta_{i} \in D$ dəyişənləri üçün müvafiq mənsubiyyət funksiyasından ibarət olan term (qeyri-səlis dəyişənlər) çoxluqlar təyin edilməlidir.

Qeyri-səlis qaydalar bazası proqram kodunda olan səhvlər və onların nəticələri haqda ekspert bilikləri əsasında formalaşdırılır (PT-nin sınağından başlayaraq onun istismarı müddətində baş verən səhvlər jurnalda qeyd edilir). Fərz edək ki, $n$ sayda məlum səhv var (normal səhvlər, təsadüfi səhvlər, məntiqi səhvlər, riyazi səhvlər, real mühitdə işləyərkən yaranan səhvlər və s.). Proqram kodunda meydana gələn səhvləri $F=\left\{\alpha_{1}, \alpha_{2}, \ldots \alpha_{n}\right\}$ ilə göstərək. Bu səhvlər nəticəsində yaranan nasazlıqlar $D=$ $\left\{\beta_{1}, \beta_{2}, \ldots \beta_{m}\right\}$ olsun. Burada $m$ mümkün ola biləcək nasazlıqların ümumi sayıdır.

Şəkil 2. Qeyri-səlis məntiq əsasında qərarın qəbul edilməsi

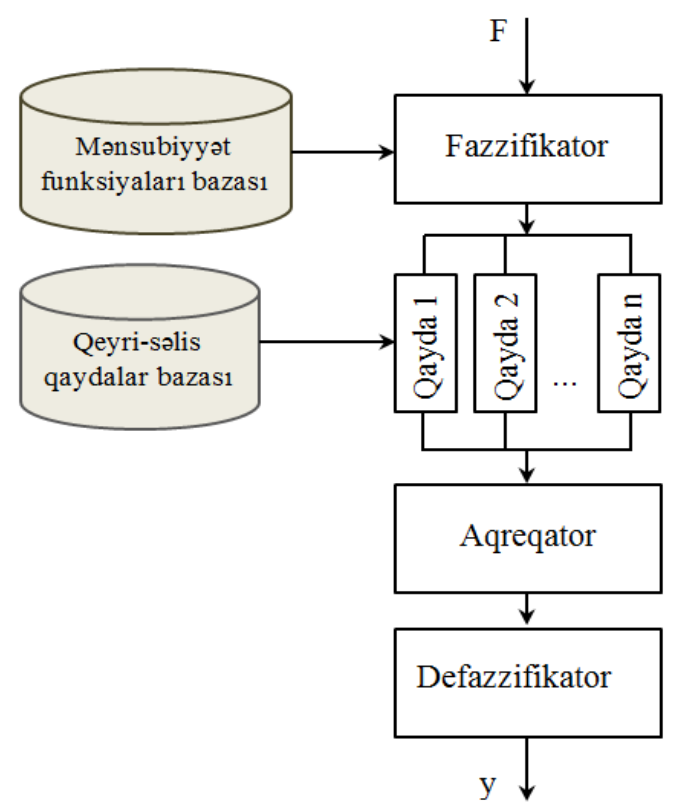

Bu baza adətən aşağıdakı şəkildə formalaşdırılır:

$$
\begin{gathered}
i=\overline{1} n \\
\text { Qayda } i \text { : IF Şərt_ } i \text { THEN Qərar } \_i\left(K_{i}\right) \\
\text { (RULE_ } \left.i \text { : IF Condition_ } i \text { THEN Conclusion_ } i\left(K_{i}\right)\right)
\end{gathered}
$$

$K_{i}$ müvafiq qaydaların çəki əmsalıdır.

Fazzifiaksiya (Fuzzification) mərhələsini qeyri-səlisliyə çevrilmə də adlandırırlar. Bu mərhələnin məqsədi giriş dəyişəninin konkret (ədədi) qiyməti əsasında həmin termə uyğun gələn mənsub iyyət funksiyasının qiymətini hesablamaqdan ibarətdir.

Aqreqatlaşdırma (Aggregation) qeyri-səlis sistemin hər qaydası üzrə şərtlərin doğruluq dərəcəsini müəyyən edən prosedurdur. Ogər bir neçə şərt yoxlanırsa aqreqatlaşdırma hər iki şərtin doğruluq dərəcəsi əsasında yekun nəticəni müəyyən edir (qeyrsəlis konyuksiya “AND” və ya dizyunksiya “OR”).

Defazzifikasiyanın (Defuzzification) məqsədi çıxış dəyişənlərinin hər biri üçün dəqiq qiymətlərin hesablanmasından ibarətdir. $\mathrm{Bu}$ zaman defazzifikasiya metodlarından (ağırlıq mərkəzi metodu, sahənin mərkəzi metodu, sol modal qiymət metodu, sağ modal qiymət metodu və s.) istifadə edilir.

Çıxış qiyməti hər hansı bir qərarın qəbul edilməsi üçün əsas götürülə bilər (adi səhvlər, qeyri-normal səhvlər, təsadüfi səhvlər və s.). 


\section{“Informasiya tohlükosizliyinin aktual problemlori” \\ III respublika elmi-praktiki seminarı, 08 dekabr 2017-ci il}

$\mathrm{Bu}$ prosesdə neyron şəbəkələrin özünü təlim funksiyalarını tətbiq etməklə məlum olmayan səhvlərin və nasazlıqların da bazaya əlavə edilməsi və növbəti hallarda aradan qaldırılmasını təmin etmək olar.

\section{NӘTİCə}

Araşdırmalar gtöstərir ki, adi statistik metodlar əvəzinə intellektual neyron şəbəkələrin və hibrid texnologiyaların tətbiqi PT-nin etibarlılığının proqnozlaşdırılmasında əhəmiyyətli dərəcədə irəliləyişlərə gətirmişdir. Bu intellektual və statistik metodlar arasında hansının daha yaxşı olduğunu müəyyən etmək çətindir. PT-nin qiymətləndirilməsində istifradə edilən hər bir model müxtəlif proqnozlaşdırma və qiymətləndirmə qabiliyyətinə malikdir. Bu modellərin birgə tətbiqi daha səmərəli nəticələr almağa imkan verir [18].

İşdə qeyri-səlis məntiq və neyron şəbəkənin birgə tətbiqi nəticəsində özünü idarə edən PT modelinin konseptual modeli verilmişdir (ilkin variantda). Belə bir modelin işlənilməsi PT-nin etibarlılı̆̆ının artırılması istiqamətində böyük əhəmiyyətə malikdir. Proqramların təhlükəsizliyini və etibarlılı̆̆ını təmin etmək məqsədilə özünü avtomatik olaraq bərpa edən proqram təminatlarının işlənilməsi İT sənayesinin əsas məqsədlərindən biridir. Xaker hücumlarından qorunmaq və proqramların etibarlılığını artırmaq üçün proqram təminatının özünüidarə metodlarının təcrübədə tətbiqi PT-nin interaktivliyini, çevikliyini və dayanıqlığını artıracaqdır. Bu həm də tam avtonom sistemin yaradılması məsələsinin həlli ola bilər.

$\mathrm{Bu}$ sahədə artıq ilk işlərin görülməsinə baxmayaraq, məsələ öz aktuallığını qoruyub saxlamaqdadır.

\section{ӘDӘBIYYYAT}

[1] http://www.mit.jyu.fi/ope/kurssit/TIES462/Materiaalit/IEEE_SoftwareEng Glossary.pdf, p.84.

[2] Kazımov T.H., Bayramova T.A. Proqram təminatinin etibarliliğinin qiymətləndirilməsi modelləri // İnformasiya Texnologiyaları Problemləri, 2017, №1, s.112-118.

[3] Tian L., and Noore A. Computational Intelligence Methods in Software Reliability Prediction, Computational Intelligence in Reliability Engineering (SCI) 39, 2007, pp.375-398.

[4] Dick S., Kandel A., Computational Intelligence in Software Quality Assurance, World Scientific Publishing Co. 2005.

[5] Khatatneh K, Mustafa $T$ Software Reliability Modeling Using Soft Computing Technique. European Journal of Scientific Research, 2009, pp.147-152.

[6] Raj Kiran N., Ravi V. Software Reliability Prediction by Soft Computing Techniques, J. Syst. Software, 2007.

[7] Zadeh Lotfi A., Fuzzy Logic Neural Networks and Soft Computing, Communications of the ACM, March 1994, Vol.37, No.3, pp.77-84.

[8] Aliyev R.A., Aliyev R.R., Soft Computing and Its Applicatons, World Scientific, 2001, p.444.
[9] Karunanithi N., Malaiya Y. K., The scaling problem in neural networks for software reliability prediction, in Proc. Third International IEEE Symposium of Software Reliability Engineering, 1992, pp. 76-82.

[10] Karunanithi N., Whitley D., Malaiya Y. K., Using neural networks in reliability prediction, IEEE Software, 1995, pp.53-59.

[11] Kaswan KS, Choudhary S, Sharma K Software Reliability Modeling using Soft Computing Techniques: Critical Review. / Information Technology \& Software Engineering, 2015, Vol. 5, No 1, p.9: 144. doi:10.4172/21657866.1000144

[12] Katiyar N, Singh R Effect of Neural Network for Prediction of Software Reliability. VSRD-IJCSIT, 2011, Vol. 1, pp. 490-500.

[13] Liang Tian, Afzel Noore. Evolutionary neural network modeling for software cumulative failure time prediction. 2005, Vol. 87, No.1, pp.45-51.

[14] Kirti Tyagi, Arun Sharma. An adaptive neuro fuzzy model for estimating the reliability of component-based software systems, 2014, Vol. 10, No1-2, pp.38-57.

[15] S. Aljahdali and N. C. Debnath, Improved Software Reliability Prediction through Fuzzy Logic Modeling / 13th International Conference on Intelligent and Adaptive Systems and Software Engineering, Nice, France, 2004, pp. 17-21.

[16] Chatterjee S., Nigam S., Singh J. B., Upadhyaya L. N. Application of fuzzy time series in prediction of time between failures \& faults in software reliability assessment, Fuzzy Information and Engineering journal, 2011, Vol. 3, No.1, pp. 293-309.

[17] Paramasivam S. Evaluation of GP model for software reliability. Proceeding of the International Conference on Signal Processing Systems, 2009, IEEE Xplore Press, Singapore, pp: 758-761. DOI 10.1109/ICSPS.2009.104

[18] Sultan H. Aljahdali, Mohammed E. El-Telbany. Genetic Algorithms for Optimizing Ensemble of Models in Software Reliability Prediction, ICGST-AIML Journal, 2008, Vol. 8, No 1.

\section{SOFTWARE RELIABILITY MAINTENANCE BY SOFT COMPUTING TECHNIQUES}

Kazimov T.H. ${ }^{1}$, Bayramova T.A. ${ }^{2}$

${ }^{1,2}$ Institute of Information Technology of ANAS, Baku, Azerbaijan ${ }^{1}$ tofig@mail.ru, ${ }^{2}$ tamilla@iit.ab.az

Abstract - The article provides information on the application of soft computing methods to evaluate software and given classification of these methods. A conceptual model based on fuzzy logic for identifying errors in software and decision-making is given.

Keywords - soft computing, fuzzy logic, chaos theory, neurocomputing, genetic algorithm 